\title{
İç Anadolu'da enfeksiyöz bronşit virüsü aşılamasının etkinliği
}

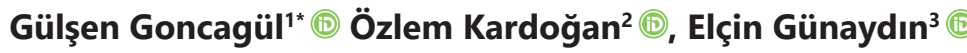 \\ ${ }^{7}$ Bursa Uludağ Üniversitesi, Mennan Pasinli Atçılık Meslek Yüksekokulu, Bursa, Türkiye \\ ${ }^{2}$ Veteriner Kontrol Merkez Araştırma Enstitüsü Müdürlüğü, Kanatlı Hayvan Hastalıkları Teşhis Laboratuvarı, Ankara, Türkiye \\ ${ }^{3}$ Kastamonu Üniversitesi, Veteriner Fakültesi, Mikrobiyoloji Anabilim Dalı, Kastamonu,Türkiye
}

Geliş Tarihi / Received: 17.09.2020, Kabul tarihi / Accepted: 19.10.2020

\begin{abstract}
Özet: Enfeksiyöz bronşit virüsü (IBV) kümes hayvanlarında solunum sistemini etkileyen, akut ve hızla yayılan, yumurta verim ve kalitesini etkileyerek ekonomik kayıplara neden olan bir virüstür. Dünya çapında bir dağılımı ve \%100'e ulaşabilen yüksek morbidite oranı vardır. Araştırmamızda İç Anadolu Bölgesi'ndeki 11 yumurtacı kümesten alınan, 599 adet kan örneği incelenmiştir. IBV ile aşılanan kümeslerden toplanan 599 adet kan serum örneğinde, bir kümeste, düşük titre (842) ve yüksek CV (\%84) (antikor titre değerlerinin sürü içindeki homojenitesi) saptanmıştır. Tüm sonuçlar değerlendirildiğin de iki kümeste ise antikor titresi 2318 ve 1283 elde edilirken, \%CV değerleri sırasıyla 93 ve 90 bulunmuştur. Diğer 8 kümesten elde edilen antikor titrelerinin 1 ile 18903, \%CV değerlerinin ise 0 ile 63 arasında değiştiği bulunmuştur. Sonuç olarak araştırmamıza dahil olan kümeslerden elde edilen antikor titreleri ve \%CV değerlerine bakıldığında; yüksek antikor titreleri-yüksek \%CV değerleri veya düşük antikor titreleri-yüksek \%CV değerleri, halen ülkemizde aşılama ile ilgili sorunların varlığını göstermektedir. Bu durum kümeslerde arzulanan homojen antikor titrelerine ulaşılmaması nedeniyle, kanatlı sürülerini enfeksiyon riskiyle karşı karşıya getirebileceği kanaatindeyiz.
\end{abstract}

Anahtar kelimeler: Aşı, ELiSA, Enfeksiyöz Bronşit

\section{The efficacy of infectious bronchitis virus vaccination in Central Anatolia}

\begin{abstract}
Infectious bronchitis virus (IBV) is an acute and rapidly spreading virus that affects the respiratory system in poultry, causing economic losses by affecting egg yield and quality. It has a worldwide distribution and a high morbidity rate reaching $100 \%$. In our research, 599 blood samples collected from 11 laying flocks in Central Anatolian region were examined. In 599 blood serum samples collected from IBV vaccinated flocks, low titer (842) and high CV (84\%) were detected in one of the flocks. When all results were evaluated, antibody titres of 2318 and 1283 were obtained in two flocks, while CV\% values were found to be 93 and 90 , respectively. It was found that antibody titers from the other 8 poultry houses ranged from 1 to 18903, and CV\% values ranged from 0 to 63 . As a result, when we look at the antibody titers and CV\% values obtained from the poultry houses included in our study; high antibody titers-high CV\% values or low antibody titers- high CV\% values, indicated the existence of vaccination-related problems in our country. We believe that this may confronted poultry flocks at risk of infection due to the desired homogeneous antibody titres are not achieved in the poultry houses.
\end{abstract}

Keywords: Vaccination, ELISA, Infectious bronchitis

\section{Giriş}

Enfeksiyöz bronşit, kanatlı hayvan endüstrisindeki özellikle genç, yetişkin yumurtacı ve broiler tavukların, solunum ve ürogenital sistemlerinde lezyonlara yol açan bu nedenle karkas gelişimi, yumurta kalitesinde düşmeye neden olan prevalansı yüksek ve önemli ekonomik kayıplardan sorumlu akut, yüksek derecede bulaşıcı viral bir enfeksiyondur (Cavanagh ve Nagi 1997; de Witt ve ark. 2011).

IBV'u tek iplikçikli, RNA genomu içeren, zarfIı bir korona virüsdür (Cavanagh 1997). Virusun, Spike (S) Glikoprotein, membran veya matrix (M) Glikoprotein, ve nukleokapsid (N) olmak üzere 3 adet spesifik proteinleri tespit edilmiştir. Çok önemli olan Spike Glikoprotein iki yapıda (S1 ve S2) olarak görülmektedir (Cavanagh ve ark. 1986). IBV sık sık genotip ve antijenik özelliklerini, doku tropizmini, patojenitesini ve sonunda hastalığın seyrini değiştirir (Cook ve ark. 2012).

Enfeksiyöz bronşit (IB) tavukların oldukça bulaşıCl, akut solunum yolu hastalığıdır. Hastalık güçlükle soluma, öksürük, trakeal raller, hapşırma ve burun akıntısı ile karakterizedir. Genç hayvanlarda ciddi solunum sıkıntısı ve özellikle civcivlerde semptomlara ilave olarak burun akıntısı oluşturabilir (Esendal 2002). Her ne kadar bu virüs gerçekten solunum yolu hastalıklarına neden olsa da, solunum sistemi dışında böbrek ve genital sistem epitelyal hücrelerin çoğunda çoğalarak patolojik değişikliklere neden olabilirler (Boltz ve ark. 2004). Genital sistemde meyda- 
na getirdiği patolojik değişiklikler yumurta veriminde azalma, yumurta kalitesinde ve yumurta kabuğu kalitesinde bozulmalarına neden olan yumurtalık hasarlarına neden olmaktadır. Diğer taraftan virusun bazı variant suşlarının böbreklerde meydana getirdiği hasar ise, yüksek ölümlerin nedeni olabilir (OIE 2000). Ölümler çoğunlukla solunum sistemine yerleşen başta Escherichia coli olmak üzere Mycoplasma spp. gibi bakteriyel kaynaklı sekonder enfeksiyonlar sebebiyle olur (Cavanagh 2003). Bunun yanında enfeksiyöz bronşitis, kanatlı hayvanlarda canlı ağırlık kayıplarına, yem dönüşüm oranlarının azalmasına, damızlık sürülerde yumurta üretimini ve kuluçka verimini olumsuz etkileyerek ekonomik kayıplara neden olmaktadır (Cook 2002).

IB virusunun genetik yapısını hızlı ve kolay bir şekilde mutasyona uğratması nedeniyle farklı serotiplerin tanımlanmasını ve enfeksiyonun aşı ile kontrol altına alınmasını zorlaştırmaktadır (Cavanagh ve ark. 1992; Lee and Jackwood 2000). IB virusunun Massachuset ve Connecticut şuşlarının solunum sistemine, T, Gray ve Holte suşlarının böbreklere affinite gösterdiği bilinmektedir (Cook ve ark. 2012). IB 4/91 susunun yaşlı tavuklarda ölüm ve \%50'ye varan yumurta verim kaybına sebep olduğu İngiltere'de rapor edilmiştir (Ballal ve ark. 2005). IB, tavuk sürülerinin aşılanmasıyla kontrol edilebilir ancak virüsün farklı suşlarıyla yapılan sürü aşılamalarında antijenik olarak ilişkili olmayan serotiplere karşı çapraz koruma bulunmamasından dolayı aşılanmış sürülerde hala enfeksiyonlar çıkabilmektedir (Cardoso ve ark. 2006; Jia ve ark. 1995). Ülkemizde halen Connecticut, H120, Ma5 ve M41 gibi farklı suşlarla infeksiyöz bronşite karşı aşılama yapılmasına rağmen Türkiye'de halen birçok IB şüpheli salgınlar yaşanmaktadır (Kahya ve ark. 2013).

IB tanısı klinik bulgulara, öyküye, lezyonlara, serokonversiyon veya antikor seviyelerine, virüs izolasyonuna ve viral RNA'nın saptanmasına dayanır (Cavanagh ve Naqi 1997). IBV, yüksek derecede immünojeniktir ve enzime bağlı immünosorban (ELISA) testi ile tespit edilebilen antikorların üretimini uyarır. $\mathrm{Bu}$ nedenle ELISA IBV'ye özgü antikor seviyelerini ölçmek için muhtemelen en sık kullanılan analizdir (Okino ve ark. 2014).

Bu çalışmanın amacı, günümüzde Türkiye'de İç Anadolu Bölgesi'nde yetiştirilen yumurtacı sürülerde ELISA'yla IBV'ye özgü antikorların varlığı ile aşılama etkinliğini belirlemektir.

\section{Gereç ve Yöntem}

\section{Gereç}

Çalışma materyali olarak, IBV karşı aşılanmış, iç Anadolu Bölgesi'nin farklı illerinde (Ankara, Eskişehir, Çorum) bulunan 11 yumurtacı sürülerden alınan 599 adet kan örneği kullanılmıştır. Alınan kan örnekleri soğuk zincir altında laboratuvarına getirilmiştir Kan örneklerinin serumları santrifüj yoluyla ayrılarak ELISA uygulanıncaya kadar $-20^{\circ} \mathrm{C}$ 'de derin dondurucuda saklanmıştır.

Tablo 1. Aşılar ve Aşılama Programı

\begin{tabular}{|c|c|c|c|c|c|c|}
\hline \multirow{2}{*}{ Sürü No } & \multirow{2}{*}{ Yetiştirme Tipi } & \multirow{2}{*}{$\begin{array}{c}\text { Yaş } \\
\text { (Hafta) }\end{array}$} & \multirow{2}{*}{ Numune Sayısı } & \multicolumn{3}{|c|}{ Kullanılan Aşılar ve Uygulama Sayısı } \\
\hline & & & & 1.(Aktif) & 2. (Aktif) & 1.(İnaktif) \\
\hline 1 & Yumurtacı & 25 & 225 & Ma5 + Clone 30 & IB H120 & $\mathrm{COR} 4+\mathrm{IB}+\mathrm{ND}+\mathrm{EDS}$ \\
\hline 2 & Yumurtacı & 12 & 29 & Ma5 + Clone 30 & Ma5 + Clone 30 & \\
\hline 3 & Yumurtacı & 15 & 24 & Ma5 + Clone 30 & Ma5 + Clone 30 & \\
\hline 4 & Yumurtacı & 14 & 75 & Ma5 + Clone 30 & Ma5 + Clone 30 & \\
\hline 5 & Yumurtacı & 13 & 78 & Ma5 + Clone 30 & Ma5 + Clone 30 & \\
\hline 6 & Yumurtacı & 12 & 25 & Ma5 + Clone 30 & Ma5 + Clone 30 & \\
\hline 7 & Yumurtacı & 10 & 28 & Ma5 + Clone 30 & Ma5 + Clone 30 & \\
\hline 8 & Yumurtacı & 9 & 26 & Ma5 + Clone 30 & Ma5 + Clone 30 & \\
\hline 9 & Yumurtacı & 14 & 26 & Ma5 + Clone 30 & Ma5 + Clone 30 & \\
\hline 10 & Yumurtacı & 12 & 40 & Ma5 + Clone 30 & Ma5 + Clone 30 & \\
\hline 11 & Yumurtacı & 11 & 23 & Ma5 + Clone 30 & Ma5 + Clone 30 & \\
\hline \multicolumn{3}{|c|}{ Toplam Serum Sayısı } & 599 & & & \\
\hline
\end{tabular}




\section{Yöntem}

\section{ELISA Kiti}

Çalışmamızda BIOCHEK firmasına ait BioChek "Infectious Bronchitis Antibody Test Kit ${ }^{\circledR}$ " (Katalog kodu CK 119) ELISA kitleri kullanılmıştır.

\section{Uygulama}

Yukarıda aşılama programı verilmiş tavuk serum örnekleri teste başlamadan önce 1:500 oranında sulandırıldı. Kit içinde bulunan negatif kontrol, pozitif kontrol ve sulandırılmış serum örnekleri (100 $\mu \mathrm{l})$, inaktive edilmiş IBV antijeni ile kaplanmış mikropleyt gözlerine ayrı ayrı usulüne uygun olarak eklendi. Pleytlerin A1 ve B1 çukurlarına $100 \mu$ l negatif kontrol serumu konuldu. C1 ve D1 gözlerine $100 \mu \mathrm{l}$ pozitif kontrol serumu konuldu ve oda sıcaklığında 30 dakika bekletildi. Böylece, IBV antikoru içeren serum örnekleri pleyt gözlerine IBV antijenlerine bağlanarak antijen-antikor kompleksleri oluşturuldu. Pleyt gözlerindeki içerikleri aspire edilerek 4 kez yıkama solüsyonu (her bir göz için $350 \mu l$ ) ile yıkandı. Pleytler kurutma kağıtlarına ters çevrilerek fazlalıklar alındı. Böylece, özel yıkama solusyonu ile pleytin yıkanması sonucunda non spesifik antikorlar ve diğer serum proteinleri ortamdan uzaklaştırılmış oldu. Daha sonra pleytlere $100 \mu$ l olacak şekilde konjugat reagent uygulandı ve oda sıcaklığında 30 dakika bekletildi. Konjugat reagent (alkalin fosfataz enzimi ile etiketlenmiş anti-chicken lgG) eklenerek orijinal tavuk IBV antikorları bağlanmaktadır. Tekrar her bir pleyt gözleri 4 kez yıkandı. Bu yıkama işlemi ile işlevi tamamlamış konjugat ortamdan uzaklaştırılmış oldu. pNPP ( $p$-Nitrofenil fosfat) formundaki substrat, boya olarak olarak eklendi. Her bir pleyt gözleri $100 \mu$ l substrat eklenerek 15 dakika oda Isısında

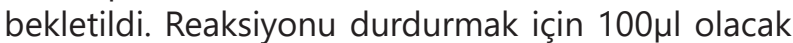
şekilde pleyt gözlerine durdurma solüsyonu eklendi. Oluşan sarı renk, serum örneklerindeki antikor miktarına bağlı olarak yoğunluk göstermektedir. Kit üreticisi firmanın önerileri doğrultusunda, Optik dansite (OD) Bio Tek ELx808 Marka ELISA Reader'da 405 $\mathrm{nm}$ 'de okundu. Değerlendirme kit üreticisi firmanın önerileri doğrultusunda yapıldı. Elde edilen ELISA sonuçları, aşı etkinliği yönünden değerlendirildi.

\section{Bulgular}

Yumurtacı sürülerden toplanan 599 kan serumunun indirekt ELISA yöntemi ile antikor titresi sonuçları elde edilmiştir. \%CV olarak gösterilen değer, antikor titre değerlerinin sürü içindeki homojenitesini göstermektedir. Hesaplanan CV değeri ne kadar küçük- se, sürü antikor titre değerleri açısından o kadar homojendir ya da değer ne kadar büyükse sürü antikor titre değerleri o kadar heterojendir. Biz değerlendirmemizde uygun \% CV değeri 45 olarak belirledik (Tablo 2).

Tablo 2. Enfeksiyöz bronşit hastalığı için ELISA titre ve \%CV değerleri (Dilüsyon 1:500)

\begin{tabular}{ccccl}
\hline $\begin{array}{c}\text { Sürü Kan Serum } \\
\text { No }\end{array}$ & $\begin{array}{c}\text { IBV } \\
\text { Odedi } \\
\text { Titre }\end{array}$ & $\begin{array}{l}\text { \%lama } \\
\text { Titre }\end{array}$ & Yorum \\
\hline 1 & 225 & 12620 & 42 & Titre yeterli-CV normal \\
\hline 2 & 29 & 3574 & 93 & $\begin{array}{l}\text { Titre yeterli-CV yüksek / } \\
\text { asılama sorunu }\end{array}$ \\
\hline 3 & 24 & 7204 & 45 & Titre yeterli-CV normal \\
\hline 4 & 75 & 2009 & 90 & $\begin{array}{l}\text { Titre yeterli-CV yüksek / } \\
\text { aşlama sorunu }\end{array}$ \\
\hline 5 & 78 & 5407 & 56 & Titre yeterli-CV normal \\
\hline 6 & 25 & 11008 & 33 & Titre yeterli-CV normal \\
\hline 7 & 28 & 1139 & 84 & $\begin{array}{l}\text { Titre düşük-CV yüksek/ } \\
\text { aşllama sorunu }\end{array}$ \\
\hline 8 & 26 & 8951 & 26 & Titre yeterli-CV normal \\
\hline 9 & 26 & 2224 & 51 & Titre yeterli-CV normal \\
\hline 10 & 40 & 7079 & 45 & Titre yeterli-CV normal \\
\hline 11 & 23 & 3651 & 40 & Titre yeterli-CV normal \\
\hline
\end{tabular}

Çalışmamızda 11 sürünün tamamına infeksiyöz bronşite karşı 2 aktif aşılama uygulandığı (1. uygulama ilk hafta, 2. uygulama 3. veya 4. hafta) sadece test edilen bir sürüde inaktif aşı yapıldığı öğrenilmiştir. Numune alınan 1. sürüde, Ma5 + Clone 30, IB H120 aktif ve inaktif (COR4+IB+ND+EDS) aşılama uygulanmıştır. Bu sürüde antikor titresinin yüksekliği inaktif aşılamanın olmasına bağlanmıştır. Aşılama yapılmış 2. ve 4. sürülerde ortalama titre yeterli iken yüksek CV (\%93 - \%90) bulunması bu firmalarda aşılama sorununun olduğunu düşündürmüştür. Ayrıca 7. sürüde Ma5 + Clone 30 ile aşılamada beklenilen titre düzeyi alt seviyede olması buna karşın, yüksek CV (\% 84) değeri bu firmada da aşılama sorununu gündeme getirmiştir. Aktif aşılama (Ma5 + Clone 30) yapılan diğer sürülerde ortalama antikor titreleri 2224 ile 11008 arasında bulunmuştur. Ortalama titreleri yeterli bulunan sürülerde elde edilen \%CV değerleri 26 ile 56 arasında kabul edilebilir sınırlarda bulunmuştur. Sürü 6'ya ait olan numunelerde ortalama antikor titresi 11008 bulunarak yüksek görülmekle birlikte \%CV bakımından \%33 ile düşük CV'ye sahip olduğu saptanmıştır. Bu sürü ile ilgili daha fazla detay bilgi sağlanabilseydi uygun görülen ortalama titre değerinin tam açıklaması ifade edilebilirdi. Aşılamanın olduğu 11 sürünün 8'inde enfeksiyöz bronşite karşı yeterli ortalama antikor titresi ve \%CV 
değerinin olduğu, diğer 3 sürüde ise aşılama sorunu olduğu ve/veya muhtemelen diğer IBV varyantlarının varlığı dikkati çekmektedir (Tablo 2).

\section{Tartışma ve Sonuç}

Enfeksiyöz bronşit dünyada ve ülkemizde kanatlı endüstrisindeki yumurta üretim miktarı ve kalitesini etkileyen en önemli viral infeksiyonlardan biridir. Tavukçuluk endüstrisinde sürülerde ciddi ekonomik kayıplara yol açmaktadır. Bu enfeksiyonun kontrolünde sıkı biyogüvenlik önlemleri ile birlikte kanatlıların IBV suşlarına karşı direncini arttırmak için aşılamanın büyük etkisi söz konusudur (Cook 2008).

Kanatlı yetiştiricileri düzenli aşılama yapmalarına rağmen, IBV salgınları sık görülür ve enfekte kümeslerde çok büyük ekonomik kayıplara neden olur. IBV antikor tespiti ve serolojik profil belirleme çalışmalarında, duyarlılık açısından diğer geleneksel serolojik testlere kıyasla spesifikliği ile ELISA tercih edilmiştir (Bronzoni ve ark. 2005). Aşılama özellikle viral enfeksiyonların kontrolünde en önemli adımdır. Aşılamanın immunizasyonunu, sürünün aşılama takvimi, sürü için seçilen aşı tipi, aşının uygulama yolu, uygulama tekniği, aşılanan kanatlının sağlığı ve aşı ekibinin uygulama becerisi etkilemektedir. Saha da uygulanan aşı programları enfeksiyöz bronşitin bölgedeki durumu ve aşılanacak sürünün durumuna göre farklılık gösterebilir. Bunların yanında saha şartları altında yapılan aşılamalarda, çiftlikteki hijyen şartları ve sevk idare yöntemleri de büyük önem taşıdığı için aşılardan tam anlamıyla koruma beklemek gerçekçi olmayacaktır. Çalışmamızda numunelerimizin alındığı İç Anadolu Bölgesi'nde enfeksiyöz bronşit için en yaygın kullanılan aşı suşları MA5, H120'dir. Çalışmamıza dahil olan 11 sürünün tamamına Ma5 + Clone 30 bivalan aşılama yapılmıştır. Enfeksiyöz bronşite karşı aşılamalar sonucunda 11 sürüden 10'unda elde edilen antikor titreleri yeterli bulunmuş ancak, aşılama uygulamalarının ELISA sonuçları değerlendirildiğinde her ne kadar antikor titreleri yeterli olsa da, 3 sürünün antikor titrelerinin sürü içerisindeki dağılımının homojen olmaması nedeniyle enfeksiyon riskinin varolduğunu düşündürmektedir. Cardoso ve ark (2005) 8 deney grubunda yaptıkları çalışmada, polivalan aşılarla aşılanan sürülerle monovalan aşılarla aşılananlarla sürüleri karşılaştırdıklarında, polivalan aşılamalarda aşı etkinliğinin farklı olduğu ve aşılamalardan sonra gerekli korumanın gerçekleşmediği sonucuna varmışlardır. Çalışmamızdaki sürülerde hem ND hem de IB aşıları aynı anda uygulanmıştır. Aşılama sonrası elde edilen düşük titrenin aşılar arası interferensten kaynaklandığını düşünülmüştür. Aşılar arası interferensin nedeni, ND ve IB aşılarının her ikisi de solunum sisteminde bulunan epitel hücreleri etkilemesi ile açıklanmıştır (Gelb ve ark. 2004).

Cook ve ark. (2001) IBV'nin sadece NDV ile etkileşime girmediğini, diğer Paramyxovirus ve Avian Pneumovirus grupları ile de ilişkide olabileceğini bildirmiştir. Bunun yanında enfeksiyöz bronşitis virüsünün sıklıkla genotipini değiştirmesi ve sahada bulunan IBV'ler arasındaki yüksek antijenik varyasyon nedeniyle, IB'ye karşı etkili bir aşılama programı oluşturmak oldukça zordur (Cook 2012). 2018 yılında Iran'da yapılan bir çalışmada, IBV'nin QX suşuna karşı uygulanan $\mathrm{H} 120$ ve Ma5 aşılarının virüse karşı çapraz koruma sağlayamadığı ve baskın genotiplerin IS-1494 benzeri IBV, 793/B tipi, Massachusetts ve QX tipi olduğu rapor edilmiştir.

Çalışmamızda da uygulanan $\mathrm{H} 120$ ve Ma5 aşıları sonrasında, 3 sürünün antikor titrelerinin sürü içerisindeki dağılımının yeterli olmaması çapraz koruma yönlü değerlendirilebilir. Aynı zamanda bölgesel baskın genotiplerin belirleneceği çalışmalar yapılarak, bu tiplere karşı çapraz koruma sağlanabileceği, aşılama programlarıyla çiftliklerimizdeki viral yükü azaltılabileceği öngörülmektedir. IB'nin kontrol stratejisi aşılamaya dayanır. Bu nedenle canlı ve inaktif aşılar kullanılmıştır. Bölgesel aşı programları değişebilmektedir. Her ne kadar katı biyogüvenlik ve tek yaş sistemiyle kanatlı yetiştiriciliği yapmak gibi temel kontrol önlemleri olsa da, tavukların IBV suşlarıyla mücadeleye karşı direncini arttırmak için aşılama kesinlikle gereklidir.

Aşılama, 50 yıldan uzun bir süredir IBV'yi kontrol etmek için bir önlem olarak kullanılmaktadır. Bununla birlikte, halen devam etmekte olan atteue canlı veya inaktif aşılar, virusun mutasyon veya rekombinasyon olayları kaynaklı, hızla ortaya çıkan varyant suşları ile mücadelede etkili olmadığı için zorluk devam etmektedir. Bunlara ilave olarak kullanılmakta olan canlı attenue aşılar, yeni patojenik IBV varyantlarının ortaya çıkmasına katkıda bulundukları için güvenlik endişesini artırmaktadır (Awad ve ark. 2014; Bande ve ark. 2015; McKinley ve ark. 2008).

Epidemiyolojik açıdan 2000 yıllardan bu yana IBV saha suşlarında virüs değişikliklerini anlamak için, izolasyon ve tiplendirme çalışmaları yapılmaktadır. İran'ın Fars eyaletinde bölgesel aşılama başarısızlığı ile ilgili IBV varyantlarını tespit etmek için epidemiyolojik bir araştırmada, 793/B serotipiyle ilişkili IRFIBV32 suşu, izole karakterize edilmiştir (Broomand ve ark. 2011). Ahmed ve ark. (2007) yaptığı çalışmada, dünya çapında çok sayıda IBV 
serotipi bildirilmektedir. Tunus'ta yapılan bir çalışmada, ticari H120 aşısının neden olduğu bağışıklık tepkisinden kaçınabilecek yeni IBV varyantlarının varlığı ortaya konmuştur. Bu çalışmada CR88 (793B tipi) ile H120 aşıları arasında immünolojik yanıt araştırıldığında, H120 tarafından sağlanan düşük koruma rapor edilmiştir (Bourogâa ve ark. 2009). Buna karşın çalışmamızda sürülerde sadece 1 numaralı sürünün H120 ile aşılı olduğu ve sürüde yeterli titre elde edildiği görülmüştür. Karimi ve ark. (2018)'nın yaptığı çalışmada; sahada IBV'nin civcivleri yaşamın ilk haftasında enfekte etmesi ve civcivlerin bir gün önce $\mathrm{H} 120$ veya Massachusetts IB aşıları kullanılarak aşılanması durumunda, civcivlerin tam koruma seviyesine ulaşamadığını, ancak viral yükün ve patolojik hasarlar azaltılarak IBV'ye karşı göreceli koruma sağlanabildiğini belirtmişlerdir. H120 aşısının, Belçika B1648, Fransız 84084 ve Fransız 84221 serotipleri ile heterolog mücadeleye karşı solunum yolunun bir miktar korunmasını indüklediği bulunmuştur (Cook ve ark. 1999).

Çalışmamızda numune alınan bölgede ve ülkemizde halen aşılamalara rağmen bu enfeksiyonun görülüyor olması, yeni enfeksiyöz bronşit (IB) varyant virüslerinin ortaya çıkması ve/veya çeşitli IB suşları arasında çapraz koruma olmaması ilişkilendirilebilir (Cavanagh 1997). Cook ve ark. (1999) sadece bir serotip ile aşılamanın heterolog IBV suşlarına karşı tam bağışıklığı indükleyemediğini, ancak akut heterolog IBV varyantına karşı çeşitli IBV canlı aşıları, proktotip suşlarının bir kombinasyonu kullanılarak daha yüksek bağışıklık sağlanabileceğini gösterdi. Kahya ve ark'nın (2013) çalışmasında, H120 aşısının bir günlük civcivlere bir kez uygulanmasının, Orta Doğu 885 ve 1494 IBV suşlarına karşı korumasının bulunmadığı belirtildi. Jackwood ve ark. (2003) yeni IBV varyantının ticari aşı olarak üretim zorluğuna, yüksek masraflar ve ürün validasyonları açısından zaman alıcı ve maliyetli olduğuna değinmiştir. Dünya çapında IBV'nin farklı iyi çapraz koruyucu olmayan antijenik varyantının yaygınlığının artması, etkili bir aşılama programı tasarlama sorunu giderek zorlaşmaktadır. Massachusetts IB aşı serotipi olan $\mathrm{H}$ suşunun, heterolog serotiplere karşı çapraz koruma sağlama yeteneği ile daha geniş bir serotip yelpazesini kontrol etmek için potansiyel olarak etkili olduğu bildirilmiştir (Bijlenga ve ark. 2004). Massachusetts serotip aşısının saha izolatına karşı koruma sağladığını, ancak heterolog bir aşı kullanılarak daha iyi koruma sağlanabileceği belirlenmiştir (Shapouri ve ark. 2004; Roussan ve ark. 2008). Enfeksiyöz bronşitisten korunma da, doğru aşı serotipinin seçimi, genellikle zordur (Cook ve ark. 1999).
Bu nedenle, saha ve aşı IBV suşları arasındaki antijenik ilişkilerin değerlendirilmesi, esas olarak kanatılıarda laboratuvar çapraz okuma çalışmalarını içeren standart yöntemlerin geliştirilmesi önemlidir (Bourogâa ve ark. 2014). Bhuiyan ve ark. (2018) Bangladeş'in 4 bölgesinde yaptıkları çalışmada, yumurtacılarda en yüksek ortalama IBV antikor titresini $8919.70, \%$ CV 58,86 bulmuşlardır. Çalışmamızda ise 11 sürüden 3'ü IBV antikor titresi yönünden bu çalışmadan yüksek bulunurken, \%CV değerleri bu sürülerden daha düşük bulunmuştur. Yüksek antikor titresi, farklı yaşlarda tekrarlanan canlı ve inaktif IBV aşılamadan kaynaklanabilir (Bhuiyan ve ark. 2018).

De Herdt ve ark (2001) piliçlerde IBV enfeksiyonlarıyla ilişkili ekonomik kayıplara, ağırlıklı olarak düşük ve düzensiz maternal antikor titrelerının neden olduğunu ve broyler yetiştiricilerinde IBV aşılama stratejilerinin yüksek ve tek tip antikor titrelerini hedeflemesi gerektiği sonucuna varmışlardır. Diğer yandan ise yeterli aşılama için, maternal antikor titrelerinin dikkate alınması gerektiği vurgulanmıştır. Genel olarak, maternal bağışıklığın bir dereceye kadar aşı virüsünü nötralize edebileceği söylenirken, ancak IB aşılamasından sonra bağışıklık sistemi uyarımının genel sonucunu maternal antikorun etkilemediğini bildirilmektedir (Marcin ve ark 2017). Diğer bir çalışmada ise civcivlerde, maternal antikorun IgG sınıfında olduğu, yumurta sarısının bağırsaktan emiliminden sonra sistemik hale geldiği bildirilmiştir. Anneden gelen IgG, civcivin solunum yolunda bulunabilir, ancak IgA ile karşılaştırıldığında korumadaki rolü daha az etkili olduğu bildirilmektedir (Cardoso ve ark. 2006). Diğer araştırmalarda ise, maternal antikorların bir günlük civcivlere uygulanan IB aşılarında etkin olduğu bildirmişlerdir (Cardoso ve ark. 2006). Çalışmamızda 3 hafta ara ile aktif aşılama yapılmıştır. Çoğunlukla sürülerde yeterli antikor titresinin saptanmasıyla sürülerde yüksek veya düşük maternal antikorlara titrelerine göre, birinci aşılamanın nötralizasyonunu ve ikincisininde farklı bir yanıtı teşvik ettiğini düşünmekteyiz (Cardoso ve ark. 2006)

Okino ve ark. (2013) bir günlük civcivleri çeşitli dozlarda atenüe canlı aşılarla aşılandıktan sonra IBV'ye karşı hücresel ve humoral bağışıklık tepkileri üzerine yaptıkları çalışmada; lakrimal sekresyonlar ve trakeadaki IgG ve IgA antikor düzeylerinin aşılamadan 5 gün sonra önemli ölçüde arttığını belirtmiştir. Bununla birlikte, aşı tam dozda uygulanmadığında, eksik bağışıklık tepkisi olduğu bildirilmiştir Bu çalışmada, membranlarda tam doz IB aşılamasından sonra indüklenen $\lg A$, $\lg G$ ve $C D 8^{\text {TM }} T$ hücre yanıtlarının, antiviral koruyucu bağışıkık ile iyi korele olduğu gösterilmiştir. Bu çalışma, önceki çalışmalar- 
da olduğu gibi, uygun koruyucu bağışıklık tamamen aşı dozuna bağlı olduğu vurgulanmıştır (Okino ve ark 2013). Bu durum yetersiz doz uygulamayla aşılamalar yapılan sürülerde enfeksiyon görülmesinin önemli bir nedeni olabilir. Çalışmamızda 3 sürüde yeterli bağışıklığın bulunmamasının bir nedeni de aşı uygulama eksikliğini düşündürmektedir. Enfeksiyöz bronşitise karşı aşılama ve/veya enfeksiyonu takiben kanatılıarda humoral ve hücresel bağışıklık sistemi uyarılır. IBV'ye karşı humoral antikor durumunun koruma ile tam olarak ilişkili olmadığını bilinmektedir. Enfeksiyöz bronşitise karşı üst solunum yollarının korunmasında humoral bağışıklıklığın bir işlevi olmasa da, üst solunum yolu dışındaki yapılarda IBV replikasyonunun inhibisyonunu sağlar (Cook ve ark. 1991; Gelb ve ark. 1998; Van Ginkel ve ark. 2008). Enfeksiyöz bronşitten korunmada hücresel bağışıklık belirleyici bir faktör olarak kabul edilir (Cook ve ark. 2012). Aşılanmış kanatlıların serum antikor titresinden bağımsız olarak IBV'ye karşı solunum enfeksiyonundan korunması mukozal bağışıklığa bağlanmaktadır. Kan antikorları IBV enfeksiyonlarına karşı çok etkili olmasa da, kandaki yüksek antikor seviyeleri solunum yolu mukozasına "sızma" ve böylece koruma sağlama potansiyeline sahiptir (Ignjatovic ve Galli 1994, Jackwood 2010). Sahada, hayvancılık ve yönetim koşullarının arzulanan ölçüde olmaması ve viral enfeksiyonlara sekonder bakteriyel enfeksiyonların katılmasıyla viral enfeksiyonların şiddeti artmaktadır (Matthis ve ark. 2003). Farklı araştırmalarda aşılı sürülerle, aşısız sürüler arasında karkas gelişimi karşılaştırıldığında, aşısız sürülerin canlı ağırlık artışının olumsuz etkilendiği bildirilmektedir. Bu durum IB enfeksiyonunda ekonomik olumsuzluğun diğer bir etkisidir (Otsuki ve ark. 1990; Ignjatovic ve Sapats 2000)

Çalışmamızda enfeksiyöz bronşite karşı yumurtacı sürülerde rutin aşılama etkinliği araştırılmıştır. Çalışmadan elde edilen sonuçlar; enfeksiyöz bronşite karşı yapılan aşılamaların virüse karşı önemli ölçüde koruma sağladığını göstermiştir. Bununla birlikte, aşılama başarısızlığının görüldüğü sürülerde, muhtemelen diğer IBV varyantlarınının veya standart altı yönetim uygulamalarının varlığının neden olduğu kanaatindeyiz.

Deney hayvanları kullanımı etik kurulu ve diğer etik kurul kararları ve izinler: Bu çalışma, Veteriner Kontrol Merkez Araştırma Enstitüsü Müdürlüğü Yerel Etik Kurulu'nun 10.07.2020 tarih ve 2020/12no'lu kararı ile onaylanmıştır.

\section{Kaynaklar}

Ahmed Z, Naeem K, Hameed A. (2007). Detection and seroprevalence of infectious bronchitis virus strains in commercial poultry in Pakistan. Poult Sci. 86, 1329-1335.

Awad F, Chhabra R, Baylis M, Ganapathy K. (2014). An overview of infectious bronchitis virus in chickens. Worlds Poult Sci J 70, 375 .

Ballal A, Karrar AE, ElHussein AM. (2005). Serosurvillance study on avian infectious bronsitis virus in Sudan. J Anim and Vet Advances. 4(11), 908-909.

Bande F, Arshad SS, Bejo MH, Moeini H, Omar AR. (2015). Progress and challenges toward the development of vaccines against avian infectious bronchitis. J Immunol Res. 424860. https:// doi.org/10.1155/2015/424860 PMID: 25954763].

Bhuiyan ZA, Giasuddin MD, Uddin Z, Khan M. (2018) Seroprevalence of infectious bronchitis virus in different types of chicken in Bangladesh. Asian J Med Biol Res. 4 (1), 132-136; doi: 10.3329/ajmbr.v4i1.36831)

Bijlenga G, Cook JKA, Gelb J, De Wit JJ. (2004). Development and use of the $\mathrm{H}$ strain of avian infectious bronchitis virus from the Netherlands as a vaccine: A review. Avian Pathol, 33, 550557.

Boltz DA, Nakai M, and Bahra JM. (2004). Avian infectious bronchitis virus: A possible cause of reduced fertility in the rooster. Avian Dis. 48, 909-915.

Boroomand Z, Razeghian I, Asasi K, Mohammadi A, \& Noohadani $A H$. (2011). Isolation and identification of a new isolate of avian infectious bronchitis virüs IRFIBV32 and a study of its pathogenicity. Online J of Vet Res.15, 366-80.

Bourogâa H, Miled K, Larbi I, Nsiri J, Gribaa L, Behi I, Benrhouma W, Allegui F, Sassi H, Ghram A. (2009). Avian infectious bronchitis disease in Tunisia: seroprevalence, pathogenicity and compatibility studies ofvaccine-field isolates. Arch Inst Pasteur Tunis. 86, 75-83.

Bourogâa H, Larbi I, Miled K, Hellal YK, Hassen J, Behi I, Nsiri J, Ghram A. (2014). Evaluation of protection conferred by a vaccination program based on the $\mathrm{H} 120$ and CR88 commercial vaccines against a field variant of avian infectious bronchitis virüs. J Appl Poult Res. 23, 156-164. http://dx.doi.org/ 10.3382/japr.2013-00828.

Bronzoni RV, Fatima M, Montassier S, Pereira GT, Gama NM, Sakai V, Montassier HJ. (2005). Detection of infectious bronchitis virus and specific anti- viral antibodies using a Concanavalin A-Sandwich-ELISA. Viral Immunol.18, 569-578.

Cardoso WM, Aguiar JLC, Romao JM. (2005). Effect of Associated Vaccines on the Interference between Newcastle Disease Virus and Infectious Bronchitis Virus in Broilers. Brazilian J of Poultry Science. 3, 181-184.

Cardoso WM, Gomes LP, Romão JM, Salles RPR, Teixeira RSC, Sobral MHNR, Câmara SR, Oliveira WF. (2006). Antibodies specific to infectious bronchitis in broilers in Ceará state. Brazil Arq Bras Med Vet Zootec. 58(3), 327-332.

Cavanagh D, Davis PJ, Pappin DJ, Binns MM, Boursnell ME, Brown TD. (1986): Coronavirus IBV: partial amino terminal sequencing of spike polypeptide S2 identifies the sequence ArgArg-Phe-Arg-Arg at the cleavage site of the spike precursor propolypeptide of IBV strains Beaudette and M41. Virus Res. 4,133-143.

Cavanagh D, Davis PJ, Cook J. (1992): Infectious bronchitis virus: evidence for recombination within the Massachusetts serotype. Avian Pathol. 21, 401-408.

Cavanagh D. (1997). Nidovirales: A new order comprising Coronoviridae and Arteriviridae. Arch Virol. 142, 629-633. 
Cavanagh D. \& Naqi SA. (1997). Infectious bronchitis. In B.W. Calnek, H.J. Barnes, C.W. Beard, W.M. Reid \& H.W. Yoder Jr. (Eds.), Diseases of Poultry 10th edn p. Ames, IA: lowa State University Press. P. 511-526.

Cavanagh D. (2003). Severe acute respirarory syndrome vaccine development: experience of vaccination against avian infectious bronchitis coronovirus. Avian Pathol. 32(6), 567-582.

Cook JK, Davison TF, Huggins MB, McLaughlan P. (1991). Effect of in ovo bursectomy on the course of an infectious bronchitis virus infection in line $C$ White Leghorn chickens. Arch Virol. $118,225-34$.

Cook JK, Orbell SJ, Woods MA, Huggins MB. (1999). Breadth of protection of the respiratory tract provided by different liveattenuated infectious bronchitis vaccines against challenge with infectious bronchitis viruses of heterologous serotypes. Avian Pathol. 28(5), 477-85.

Cook JKA, Huggins MB, Orbell SJ, Mawditt K, Cavanagh D. (2001). Infectious bronchitis virus vaccine interferes with the replication of avian pneumovirus vaccine in domestic fowl. Avian Pathol. 30, 233-242

Cook J. (2002). Coronaviridae. In: Jordan, F; Pattison, M; Alexander, $\mathrm{D}$ and Faragher, $\mathrm{T}$ (Eds.), Poultry diseases. (5th. Edn.), London, W. B. Saunders Co. P. 298-306.

Cook JKA. (2008). Coronaviridae. In: Pattison M, Bradbury A, editors. Poultry diseases. 6 th ed. Amsterdam: Saunders Elsevier. p. 340-349.

Cook JKA, Jackwood M, Jones RC. (2012). The long view: 40 years of infectious bronchitis research. Avian Pathol. 41, 239-50.

de Herdt P, Ducatelle AR, Uyttebroek AE. (2001). Infectious bronchitis serology in broilers and broiler breeders: correlations between antibody titers and performance in vaccinated flocks. Avian Dis. 45, 612-619.

de Wit JJ, Cook JKA, Van Der Heijden HMJF. (2011). Infectious bronchitis virus variants: a review of the history, current situation and control measures. Avian Pathol. 40, 223-235.

Esendal MÖ. (2002). Enfeksiyöz Bronsitis, Kanatlı Hayvan Hastalıkları. Editörler: İzgür.M., Akan.M., Medisan Yayınları.50. Ankara, s: 155-162.

Gelb JJ, Nix WA, Gellman SD. (1998). Infectious bronchitis virus antibodies in tears and their relationship to immunity. Avian Dis. 42, 364-74

Gelb JJr, Campion L, Ladman B. (2004). Interferência na replicação entre os vírus dabronquite infecciosa e da doença de Newcastle. In: Anais vol.1 da Conferência Apinco de Ciência e Tecnologias Avícolas. São Paulo-Brasil. p., 63-70.

Ignjatovic J Galli L. (1994). The S1 glycoprotein but not the N or M proteins of avian infectious bronchitis virus induces protection in vaccinated chickens. Archives of Virol. 138, 117-134

Ignjatovic J \& Sapats S. (2000). Avian infectious bronchitis virus. Révue Scientifique et Technique (Office Internationaldes Epizooties). 19, 493-508.

Jackwood MW, Hilt DA, Brown TP. (2003). Attenuation, safety, and efficacy of an infectious bronchitis virus GA98 serotype vaccine. Avian Dis. 47(3), 627-32.

Jackwood MW. (2010). Control of Arkansas infectious bronchitis virus by vaccination. Avian Insight. 3, 1-4.
Jia W, Karaka K, Parrish CR. (1995). A novel variant of avian infectious bronchitis virus resulting from recombination among three different strains. Arch Virol. 140, 259-271.

Kahya S, Çöven F, Temelli S, Eyigör A, Çarlı KT. (2013). Presence of IS/1494/06 genotype-related infectious bronchitis virus in breeder and broiler flocks in Turkey. Ankara Üniv Vet Fak Derg. 60,27-31.

Karimi V, Ghalyanchilangeroudi A, Hashemzadeh M, Rahimi F, Petroudi MTZ, Farahani RKH, Maghsoudloo H, Abdollahi $\mathrm{H}$ (2018). Efficacy of $\mathrm{H} 120$ and Ma5 avian infectious bronchitis vaccines in early challenge against QX strain. Virus Dis. 29(1),123-126 https://doi.org/10.1007/s13337-017-0414-4

Lee CW, Jackwood MW. (2000): Evidence of genetic diversity generated by recombination among avian coronovirus IBV. Arch Virol. 145, 2135-2148.

Marcin S, Bartlomiej T, Daria D, Tomasz S, Andrzej K. (2017) Immunological aspects of the efficiency of protectotype vaccination strategy against chicken infectious bronchitis. BMC Veterinary Res. 13,44 DOI 10.1186/s12917-017-0963-1)

Matthijs MGR, Van Eck JHH, Landman WJM, Stegeman JA. (2003). Ability of Massachusetts-type infectious bronchitis virus to increase colibacillosis susceptibility in commercial broilers: A comparison between vaccine and virulent field virus. Avian Pathol. 32, 473-481.

McKinley ET, Hilt DA, Jackwood MW. (2008). Avian coronavirus infectious bronchitis attenuated live vaccines undergo selection of subpopulations and mutations following vaccination. Vaccine. 26, 1274- 1284. https://doi.org/10.1016/j.vaccine.2008.01.006 PMID: 18262691)

OIE. Manual of standards for diagnostic tests and vaccines. Office International des Epizooties, World Organisation for Animal Health, Paris. 2000. www.oie.int Erişim Ağustos 2020)

Okino $\mathrm{CH}$, Alessi AC, Montassier MDFS, Rosa AJDM, Wang $\mathrm{X}_{\text {, }}$ Montassier HJ. (2013). Humoral and cell-mediated immune responses to different doses of attenuated vaccine against avian infectious bronchitis virus. Viral Immunol. 26(4),259-67

Okino $\mathrm{CH}$, dos Santos IL, Fernando FS, Alessi AC, Wang $\mathrm{X}$ Montassier HJ. (2014). Inflammatory and cell-mediated immune responses in the respiratory tract of chickens to infection with avian infectious bronchitis virus. Viral Immunol. 27, 383-9.

Otsuki K, Huggins MB, Cook JKA. (1990). Comparison of the susceptibility to avian infectious bronchitis virus infection of two inbred lines of white leghorn chickens. Avian Pathol. 19, 467475.

Roussan DA, Totanji WS, Khawaldeh GY. (2008). Molecular subtype of infectious bronchitis virus in broiler flocks in Jordan. Poult Sci. 87, 661-664.

Shapouri S, Mayahi MR, Asasi MK, Charkhkar S. (2004). A survey of the prevalence of infectious bronchitis virus type 4.91 in Iran. Acta Vet Hungarica. 52, 163-166.

van Ginkel FW, van Santen VL, Gulley SL, Toro H. (2008). Infectious bronchitis virus in the chicken Harderian gland and lacrimal fluid: Viral load, infectivity, immune cell responses, and effects of viral immunodeficiency. Avian Dis. 52, 608-17 